Review

\title{
Forest Adaptation to Climate Change along Steep Ecological Gradients: The Case of the Mediterranean-Temperate Transition in South-Western Europe
}

\author{
Juan F. Fernández-Manjarrés $1, *$ (i), Paloma Ruiz-Benito ${ }^{2}$, Miguel A. Zavala ${ }^{2}$, \\ J. Julio Camarero ${ }^{3}$ (D), Fernando Pulido 4 , Vânia Proença 5 (D), Laetitia Navarro 6 , \\ Roxane Sansilvestri ${ }^{1}$, Elena Granda ${ }^{1,3}$, Laura Marqués ${ }^{2,3}$, Martina Temunovič 7 (iD, \\ Cleo Bertelsmeier ${ }^{8}$, Philippe Drobinski ${ }^{9}$, Samuel Roturier ${ }^{1}$, Marta Benito-Garzón ${ }^{10}$, \\ Iñaki García de Cortazar-Atauri ${ }^{11}$, Laurent Simon ${ }^{12}$, Stephane Dupas ${ }^{13}$, Harold Levrel ${ }^{14}$ \\ and Marion Sautier 15 (D)
}

1 Laboratoire Ecologie, Systématique Evolution, CNRS-AgroParisTech Université Paris-Sud-Paris Saclay Orsay, 91405 Paris, France; roxane.sansilvestri@u-psud.fr (R.S.); elena.granda.f@gmail.com (E.G.); samuel.roturier@u-psud.fr (S.R.)

2 Forest Ecology and Restoration Group, Department of Life Sciences, Universidad de Alcalá, 28805 Alcalá de Henares, Spain; palomaruizbenito@gmail.com (P.R.-B.); madezavala@gmail.com (M.A.Z.); 1.marlopmor@gmail.com (L.M.)

3 Instituto Pirenaico de Ecología, (IPE-CSIC), Avda. Montañana, 1005, 50192 Zaragoza, Spain; jjcamarero@ipe.csic.es

4 Institute for Dehesa Research, University of Extremadura, 10600 Plasencia, Spain; nando@unex.es

5 MARETEC/LARSYS, Instituto Superior Técnico, Universidade de Lisboa, 1049-001 Lisboa, Portugal; vania.proenca@tecnico.ulisboa.pt

6 German Centre for Integrative Biodiversity Research (iDiv), Martin Luther University Halle-Wittenberg, Halle-Jena-Leipzig, Deutscher Platz 5e, 04103 Leipzig, Germany; laetitia.navarro@idiv.de

7 Department of Forest Genetics, Dendrology and Botany, Faculty of Forestry, University of Zagreb, 10000 Zagreb, Croatia; martina.temunovic@gmail.com

8 Department of Ecology and Evolution, Le Biophore, University of Lausanne, 1015 Lausanne, Switzerland; Cleo.bertelsmeier@gmail.com

9 LMD/IPSL, Ecole polytechnique, Université Paris-Saclay, ENS, PSL Research University, Sorbonne Université, CNRS, 91120 Palaiseau, France; philippe.drobinski@lmd.polytechnique.fr

10 BIOGECO, INRA, Univ. Bordeaux, 33615 Pessac, France; Marta.benito@gmail.com

11 AGROCLIM-INRA, Domaine Saint Paul, Site Agroparc CS 40 509, CEDEX 9, 84914 Avignon, France; igarcia@paca.inra.fr

12 Université Panthéon-Sorbonne (Paris 1), LADYSS, 2 rue Valette, 75005 Paris, France; Laurent.Simon@univ-paris1.fr

13 Laboratoire EGCE, Avenue de la Terrasse, Bâtiment 13, Boite Postale 1, 91198 Gif sur Yvette, France; stephane.dupas@egce.cnrs-gif.fr

14 CIRED, AgroParisTech, CIRAD, CNRS, EHESS, Ecole des Ponts ParisTech, Université de Paris-Saclay, Campus du Jardin Tropical, 45 bis, Avenue de la Belle Gabrielle, CEDEX, 94736 Nogent-sur-Marne, France; harold.levrel@agroparistech.fr

15 AGIR, INRA, Campus d'Auzeville, 24 Chemin de Borde Rouge, CEDEX, 31326 Castanet Tolosan, France; Marion.Sautier@gmail.com

* Correspondence: juan.fernandez@u-psud.fr; Tel.: +33-01-691-55401

Received: 31 May 2018; Accepted: 23 August 2018; Published: 28 August 2018 updates

Abstract: Impacts of climate change are likely to be marked in areas with steep climatic transitions. Species turnover, spread of invasive species, altered productivity, and modified processes such as fire regimes can all spread rapidly along ecotones, which challenge the current paradigms of ecosystem management. We conducted a literature review at a continental-wide scale of South-Western 
European forests, where the drier and warmer conditions of the Mediterranean have been widely used as examples of what is expected in more temperate areas. Results from the literature point to: (a) an expansion of slow-growing evergreen hardwood trees; (b) increased dieback and mortality episodes in forests (both natural and planted) mostly related to competition and droughts, and mainly affecting conifers; and (c) an increase in emergent diseases and pests of keystone-trees used in agroforestry zones. There is no consensus in the literature that fire regimes are directly increasing due to climate change, but available satellite data of fire intensity in the last 17 years has been lower in zones where agroforestry practices are dominant compared to unmanaged forests. In contrast, there is agreement in the literature that the current spread of fire events is probably related to land abandonment patterns. The practice of agroforestry, common in all Mediterranean countries, emerges as a frequent recommendation in the literature to cope with drought, reduce fire risk, and maintain biodiverse landscapes and rural jobs. However, it is unknown the extent to which the open vegetation resulting from agroforestry is of interest to forest managers in temperate areas used to exploiting closed forest vegetation. Hence, many transitional areas surrounding the Mediterranean Basin may be left unmanaged with potentially higher climate-change risks, which require active monitoring in order to understand and help ongoing natural adaptation processes.

Keywords: adaptation; social-ecological systems; early warnings; climate change; land abandonment; agroforestry

\section{Introduction}

Global policies for adapting natural and semi-natural forests to climate change seek ambitious win-win scenarios in which measures to adapt would simultaneously reduce the impacts of ongoing climate change as well as carbon emissions [1]. In Europe, for instance, public policies aim to manage forests by increasing carbon sequestration and maintaining high biodiversity while promoting the use of wood biomass to reduce dependency on fossil fuels [2]. However, at the local level, people are concerned about measures to adapt locally to climate change effects, while not necessarily mitigating its causes. For instance, forest managers need to cope with drought-induced tree mortality [3], increased fire [4] and storm risks [5], and emerging pests and diseases that attack keystone or foundation tree species [6].

Transition zones between adjacent ecological systems, such as the ecotones along altitudinal and continental gradients, where contrasting vegetation types and biomes meet, are strongly affected by climate change [7-11]. In ecotones, rapid climate change challenges local ecosystem management to a far greater extent compared to other zones that are more buffered by regional climate patterns. These gradients, however, are an opportunity to promote adaptation to climate change, as already conducted in areas exhibiting conditions similar to those expected under climate change projections. For instance, in regions such as the Mediterranean Basin, steep gradients with extremely contrasting temperatures and rainfall regimes over a few hundred kilometers have for centuries allowed different types of agriculture, husbandry, and forestry practices, which may shift because of ongoing global change [12]. Likewise, natural vegetation may be adjusting to the new conditions that already exist in the drier parts of the continent, with community turnover favoring more drought-resistant species $[13,14]$.

Here, we analyzed a continental-wide climate and vegetation gradient between Mediterranean and temperate zones in South-Western Europe with a focus on Portugal, Spain, and France. In this zone, high species and ecosystem turnovers are expected due to the interaction of two major drivers of global change: climate and land-use changes. We focused on identifying the "best-" and "worst-" case scenarios of forest management responses in the Mediterranean-temperate ecotone. In turn, these extreme scenarios would help us to identify relevant policies for adapting social-ecological 
systems (SESs) to novel climatic and land use conditions. We based our approach on the premise that solutions resembling those already implemented throughout geographically continuous SESs are probably more acceptable to stakeholders than completely new ones.

\section{Materials and Methods}

To identify the continental-wide process underlying the ecological and social changes in the study region, a diverse panel of experts conducted a literature review based on their own experience and on relevant publications [15]. In our case, the panel of experts was composed of ecologists specialized in Mediterranean ecosystems including fire control and invasive species, climatologists working on Western Europe, geographers with experience in land use in Southern France, anthropologists specialized in silvopastoralism, economists studying land use changes in the area, and agronomists specialized in crop adaptation to climate change. The objectives that limited the scope of the review were to: (a) identify the structure of the socio-ecological gradient; (b) identify major natural ecological processes in forests; (c) understand the current socio-ecological barriers for forest adaptation; (d) comprehend critical policies and early warning signs under climate change; and (e) critically discuss the land uses that may be effective in coping with climate change. In addition, we summarized the processes that might accelerate or hamper vegetation transitions along this Mediterranean-temperate study-zone.

The literature review presented here is not exhaustive but reflects the literature considered to be relevant by the panel of experts. The review covers the last two decades that corresponds approximately to the beginning of systematic studies addressing the effects of global changes on the Iberian Peninsula, mostly with respect to forest dynamics. The scope of this paper was developed during two general workshops conducted with most of the signing authors in Paris in October 2015 and Madrid in May 2016, with a subsequent exchange of mail and video-conferences and a circulation of drafts for the different sections of the work. In the first workshop, the different participants were asked to summarize their knowledge about the processes according to their own expertise: climate trends in the Mediterranean, patterns of tree mortality, climate signatures on tree growth along gradients, invasive species, land use relating to urban sprawl, and finally, rewilding due to land abandonment. From this first workshop, it became evident that the ecological process to be further explored was fire and its relation to land uses and forest transitions in unmanaged forests. These two aspects were discussed in depth at the second workshop.

In parallel, a spatially-based analysis of fire frequency and land use was carried out, because such analysis had not been made in the study region at the required scale. This analysis necessitated projecting the Corine database for Europe (https: / /and.copernicus.eu/pan-european/corine-landcover/clc-2012) onto the same output as the satellite data (geographic system WGS1984) for the fire database collected using the moderate resolution imaging spectroradiometer from the NASA Terra satellite. The analysis was conducted using the ArcGis ${ }^{\circledR} 9.3$ version (ESRI, Redlands, CA, USA), and all maps in the figures follow the ETRS89 Lambert Azimuthal Equal-Area projection. Boxplots for the frequency of fire by land use were computed using Matlab ${ }^{\circledR}$ (MathWorks, Natick, MA, USA) graphic functions. The remaining results presented in this review were obtained from the literature except for the study case on "land mosaics" which one of the participants (F Pulido) contributed as a real example of adaptation to fire risks.

Our informal network was dubbed "Tplus3" to reflect the fact that we are considering adaptation scenarios in a world that would be $3{ }^{\circ} \mathrm{C}$ warmer, meaning that temperatures will essentially affect the current distribution of ecosystems, species, and, of course, agricultural and silvicultural systems.

\section{Results}

A literature review of models showed that Western Europe is expected to experience increases in drought events, heat waves, and variability in its precipitation regimes [16], which makes the region a very good candidate to examine the effects of adaptation processes to climate change. A literature 
review of hundreds of regional climate simulations for 2050 and 2100 have been run at $10-20 \mathrm{~km}$ resolutions from the pan-European research consortium HyMeX (https:/ /www.hymex.org/) [17,18] and EURO-CORDEX research programs (https:/ / euro-cordex.net/) [19]. The most consistent trend for Mediterranean areas as predicted by all models is an increase in mean temperatures as well as more extreme high and low temperatures. The frequency of intense precipitation (e.g., intense rainfall in mountainous areas) is expected to increase in all European countries [20]. Hence, a spread of Mediterranean-like conditions, that is, greater aridification, may be expected in the areas surrounding the Mediterranean Basin, bearing in mind that new climates may have no exact analogues to previous ones [21].

\subsection{Structure of the Social-Ecological Gradient}

For managed forests, complex ecological and social changes along a climatic gradient can be characterized by constructing a simple three-axis conceptual model for the levels of precipitation, temperature, and land use intensity (Figure 1, Supplementary Material Table S1). The three-axis model represents the extremes of possible SESs along the climatic gradient.

Water-limited Mediterranean vegetation generally favors extensive land use. Cattle, sheep, goat, and free-range pig herding was common in water-limited open vegetation before the intensification of agriculture [22]. Another feature of human-made Mediterranean ecosystems is agroforestry (Figure 2), which relies on combinations of keystone tree species producing acorns, cork, pine nuts, and resin, as well as small cultivated areas and pastures [23] that create different SESs. This approach to agroforestry is not new and can even be traced back to Roman times when it was called ager-saltus-silva or field-pasture-woodland [24]. Agroforestry systems are not exclusive to the Mediterranean area, but are currently much less common in temperate European areas [25].

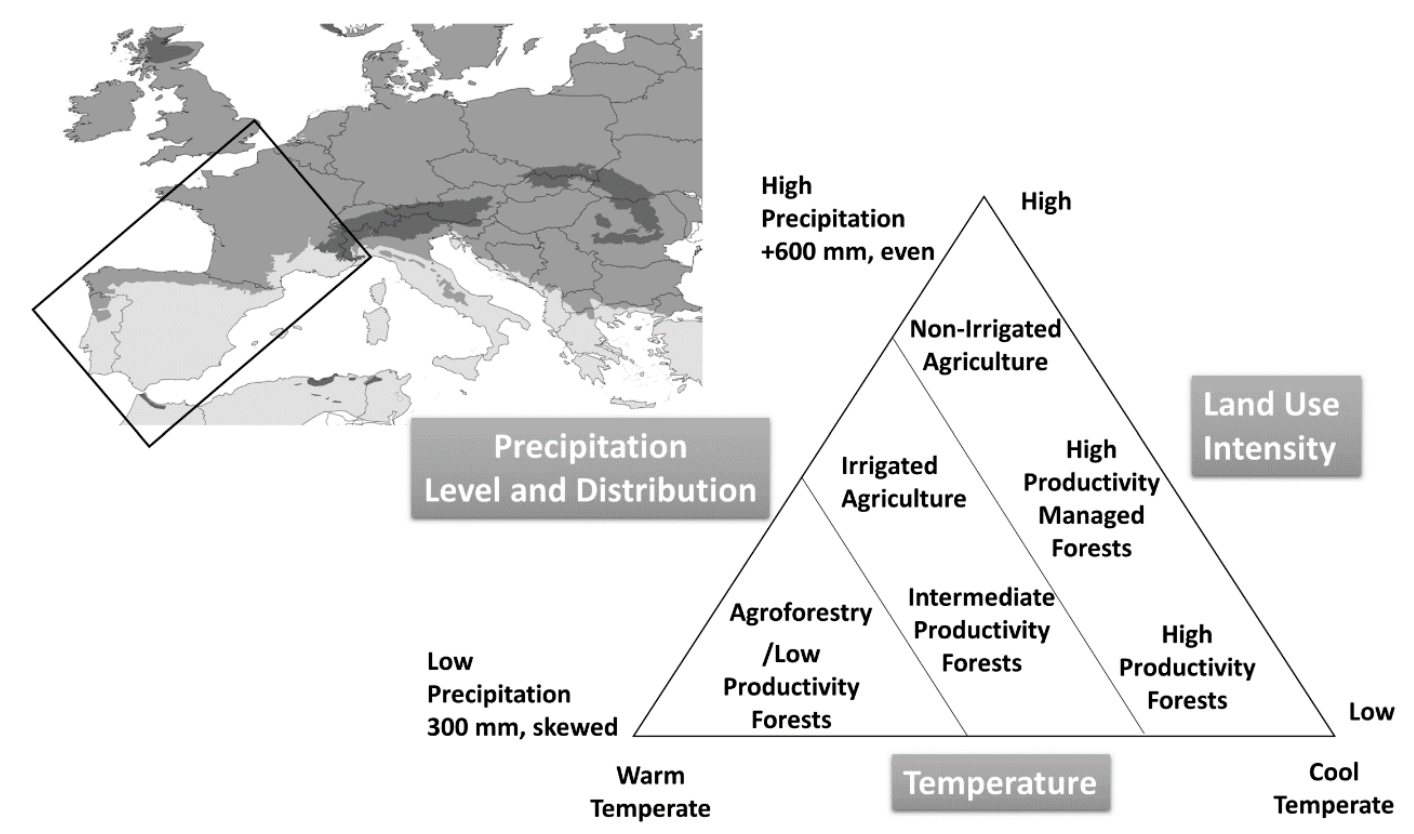

Figure 1. Conceptual figure of major ecological boundaries in socio-ecological forest systems along a climatic gradient or ecotone between Mediterranean and temperate biomes (rectangle). The insert map depicts the biogeographical zones of the Mediterranean (light gray), temperate (medium gray), and alpine areas (dark gray) (adapted from [26]). Please note that at a local level, because of mountains, similar gradients can also be found. The divisions between land uses (diagonal lines) are indicative and by no means imply that the different land uses are evenly distributed between types. 
The functional features of Mediterranean systems can vary widely, but they typically include open vegetation, a low accumulation of biomass because of grazing, and recurrent low- to medium-intensity fires during the summer dry period when little plant growth occurs [27]. Evergreen, fire-resistant, and slow-growing trees (e.g., Quercus suber, Quercus ilex) are typically the keystone tree species. The pattern of low-intensity fires in Mediterranean areas favored by open vegetation with scattered trees and grazing activities differs from recent extreme fire events that have resulted from social conflicts [28] and homogenous landscapes rich in biomass. Abandoned fields have occasionally been replaced in the Iberian Peninsula with planted forests of low management intensity or even abandoned, leading to an increase in biomass and thus creating fire-prone forests [29], with generally lower regeneration and diversity levels than natural forests [30].

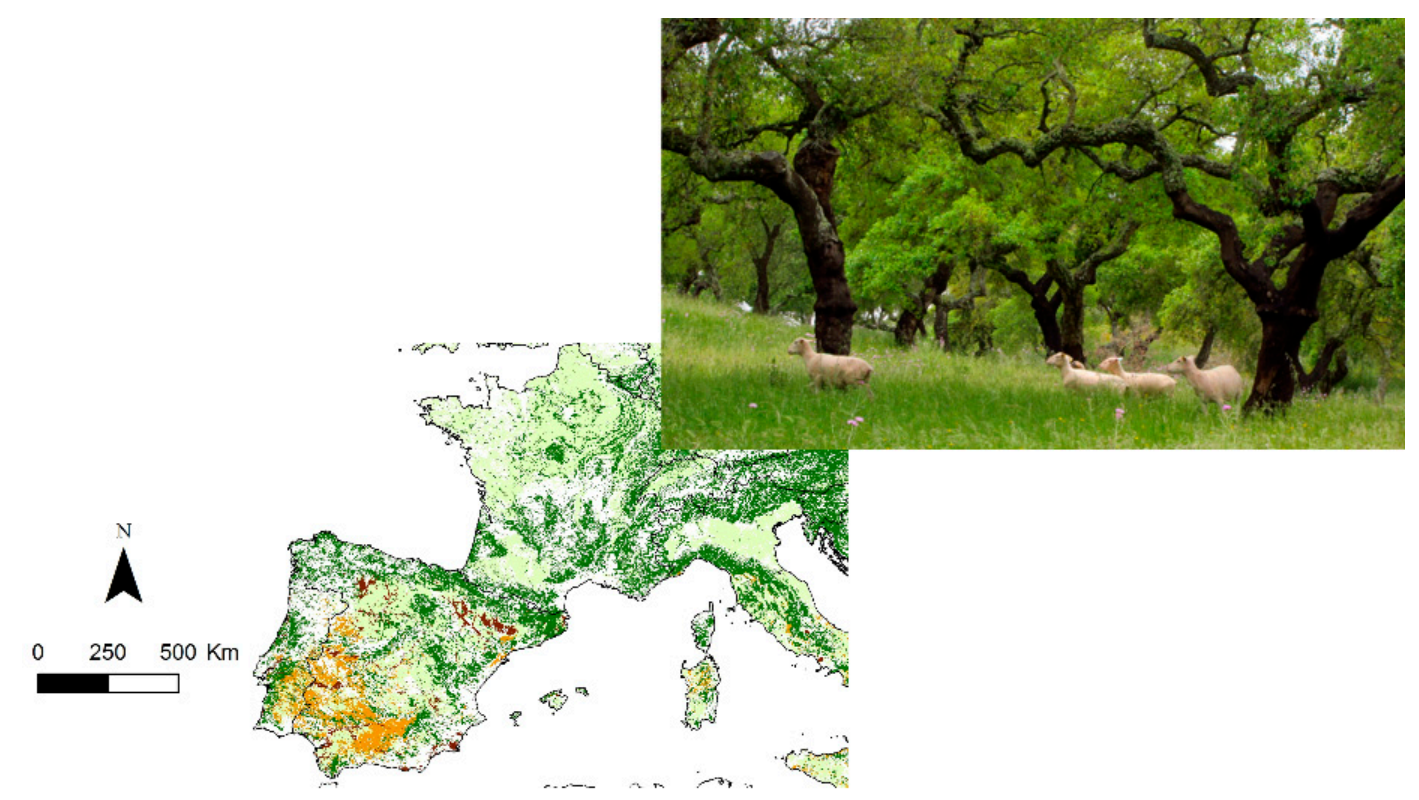

Figure 2. Agroforestry areas in South-Western Europe (brown), including olive tree plantations from the CORINE 2012 land cover maps (see text for details). Forests are depicted in dark green, non-irrigated agricultural areas in pale green, and irrigated areas in dark red. Many of these agroforestry areas are managed for trees, animals, and pastures as depicted in the inset photo of a montado in Portugal (photo credit. V. Proença).

Temperate areas in the continental-wide ecotone of the study zone (Figure 1) have mild summers, wet winters, and less precipitation seasonality than Mediterranean areas, with these conditions favoring forests of deciduous hardwoods including Quercus robur, Quercus petraea, and Fagus sylvatica. Temperate areas can have very productive mixed forests or sometimes be simplified into conifer or poplar monocultures that can be managed using relatively short rotations. For instance, the maritime pine forest (Pinus pinaster) of the Landes region in Western France is the largest $\left(10^{6} \mathrm{ha}\right)$ and one of the most productive forests in Europe. Mixed temperate forests have lower fire risks compared to conifer plantations in the Mediterranean [31]. Open husbandry is practiced in temperate areas, but remains a minor activity and is very rapidly declining (e.g., in the French Massif Central), whereas non-irrigated agriculture in former forest lands is widespread.

\subsection{Major Ecological and Social Processes along the Gradient}

Currently, the most widespread observation reported in the literature in South-Western Europe is that holm oak (Quercus ilex) and other evergreen oaks have expanded their ranges to the detriment of deciduous broadleaved species and conifers (see [32-34], Figure 3, and Supplementary Material Table S1). In some cases, the expansion of evergreen trees might have been the result of management 
decisions (e.g., [35]), but under certain conditions, evergreen oaks have expanded their range northward and upward in altitude to spontaneously replace pine or beech-dominated forests and mixed forests at the seedling or sapling stage. For instance, $Q$. ilex saplings are increasing their range northward along the French Atlantic coast into habitats not commonly associated with Mediterranean climates [36]. This northward migration has been attributed to climate change $\left(+1.5^{\circ} \mathrm{C}\right.$ between 1960 and 2000 in the study area) and the cessation of forest management, which used to favor pines in detriment of hardwood species, thus allowing the species to expand and follow secondary succession. The expansion of hardwood evergreen forests is in line with observations of tree mortality that promotes species turnover [37] as well as projections for the area. For example, drylands in the Mediterranean Basin are expected to expand [38] due to more severe droughts [39]. The transition from gymnosperm to angiosperm could be further controlled by both the climate and initial conditions of the forest structure as previously suggested in a study covering the European scale [30]. The change from gymnosperms to more oak-dominated forests might be favored by a high proportion of planted conifers in areas of the Mediterranean Basin that are not necessarily optimal for conifers, but have acted as an intermediate transient state to facilitate the transition to hardwoods by providing intermediate canopy closure. However, it is predicted that the progression of scrubland and grassland will occur in temperate regions depending on the drought patterns when dynamic vegetation models are used [40].

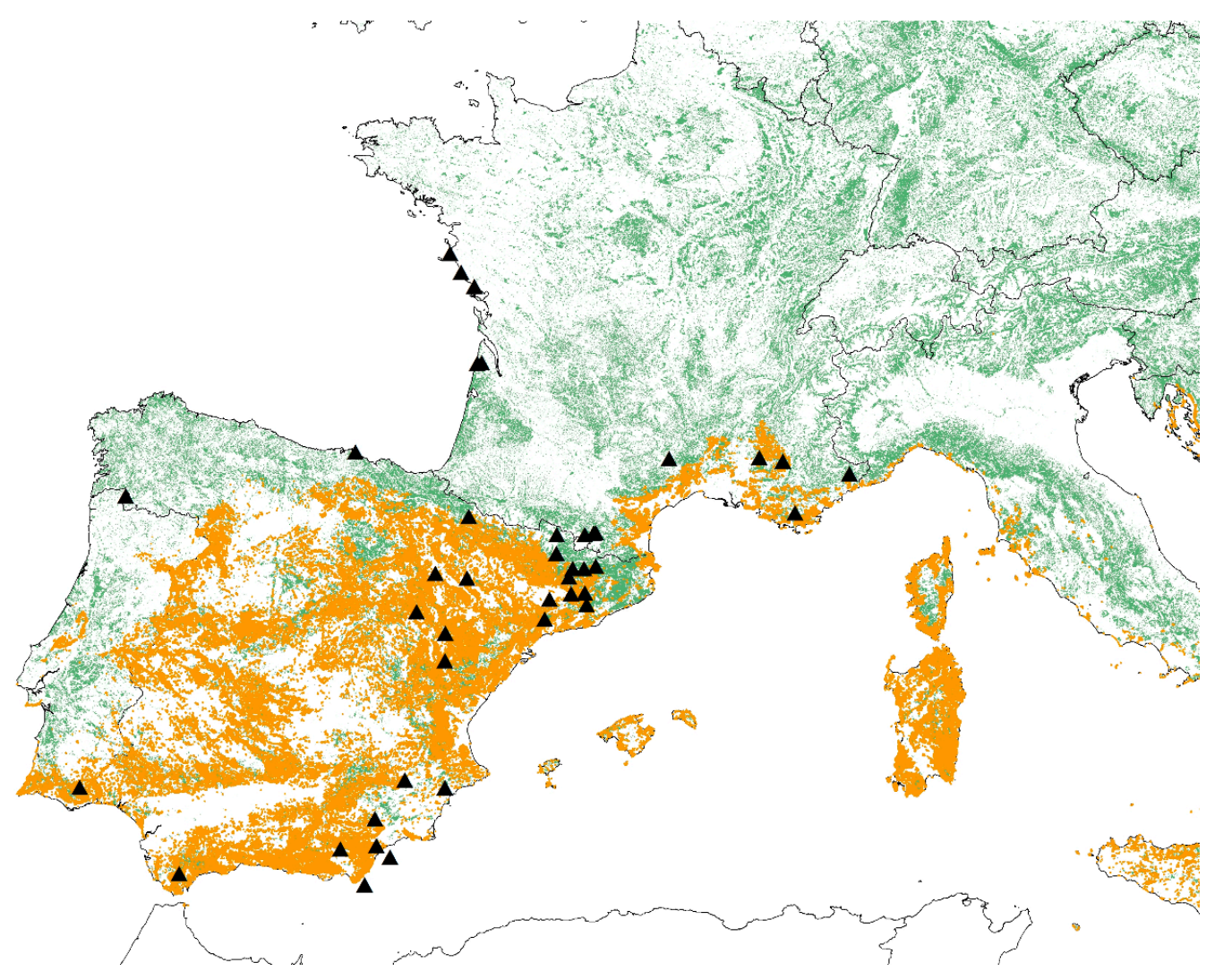

Figure 3. Current observations of increasing evergreen tree density in the study area in South-Western Europe (black triangles). Most records show the expansion of the holm oak (Quercus ilex), but other species such as Quercus pubescens and Juniperus spp. have also been recorded. See Table S1 in the Supplementary Material for point data. The brown color represents sclerophyllous and transitional vegetation, and the green color forests including green broadleaved and conifer forests from the CORINE European database for 2012.

The social dynamics along the ecotone include a slight decrease in the rural population as well as population aging in the next years. Field abandonment has been particularly marked in 
the Mediterranean region and sometimes resulted in grasslands being converted into forests and, to a lesser extent, cropland being converted into grassland [41-43]. Land abandonment is particularly high in marginal and less productive areas in Europe, including several mountainous areas [44]. Recent abandonment of fertile flat lowland has also been caused by the European Union's common agricultural policy, which aims to decrease overproduction by subsidizing lower crop yields. For the different scenarios, rural depopulation and agricultural land abandonment are consistently projected to continue for some decades and to be particularly severe in the Mediterranean Basin, where they will likely be accompanied by forest expansion [45] and large forest fires [46]. Other countries in the region, such as Italy, have forest surfaces that have also increased during the last century because of land abandonment [47], especially in mountainous areas.

The effects of land abandonment on biodiversity are not straightforward and are difficult to link directly to climate change. Land abandonment in Europe is considered to have negative effects on biodiversity [48], but in a meta-analysis of Mediterranean Basin data, both the richness and abundance of plants and animals were found to increase slightly after the land was abandoned [49]. Forests are also susceptible to be colonized by invasive species after the cessation of human activities, as observed for the American walnut in Central Europe [50], which leads to a decrease in the overall diversity.

By contrast, the abandonment of agricultural land has been critically linked to an increase in accidental fires in unmanaged forests close to urban areas [51]. Moreover, fire is of increasing concern in temperate areas, because fires tend to be scarce with a consequent lack of fire management culture. For instance, fires are increasingly seen as a threat to urban and recreational areas in the Mediterranean and temperate areas of Southern France, because the traditional knowledge of how to use them as an ecological management tool has largely disappeared. It is expected that the total burned area in Mediterranean and temperate Europe will significantly increase and almost double the current total burned area [52]. Large fires in the Mediterranean are increasingly related to drier and warmer summers, with many of them being accidental, although they are also correlated with social instability (unemployment) and criminal intent in areas where biomass accumulation has occurred in abandoned stands. In fact, at least half of all large fires are deliberately lit [46]. It is therefore expected that more fires will be started in scenarios that project continuous social decline in rural areas undergoing depopulation. In particular, urban sprawl can increase fire risks in tourist areas and zones with strong peri-urban components [51]. Overall, fire frequency and intensity is lower when the levels of biomass are low, and the vegetation is open as in agro-silvicultural systems. Indeed, when the fire events between 2000 and 2017 are overlaid over main land use in Europe, a clear pattern emerges (Figure 4): areas with conifers and mixed broadleaf-conifer forests or unattended evergreen (sclerophyllous) and transitional vegetation types have a much greater intensity of high impact fire events than areas devoted to agroforestry despite the similar frequency of fires.

\subsection{What Adaptation Lessons Can Be Inferred from the Study Zone?}

One emerging pathway for climate change adaptation in the ecotone is the implementation of extensive, low-to-medium biomass landscapes for forestry and related activities. In this context, traditional agropastoral practices used in more remote regions may serve as barriers against fire that often preclude fire expansion better than conventional firebreaks. This mosaic-like landscape configuration helps fire prevention directly, but also indirectly by keeping local people in the fields as low-cost deterrents against arsonists. Currently, a new territorial model (MOSAICO project http: //www.mosaicoextremadura.es/el-proyecto/) takes advantage of traditional concepts to design smart-fire landscapes in which conventional infrastructure and agro-pastoral plots are combined. In this model, ecosystem services provided by land managers should be valued and payed for as a means of keeping local people involved in the planning strategy (Figure 5), but this kind of subsidy does not yet exist in a generalized way. 

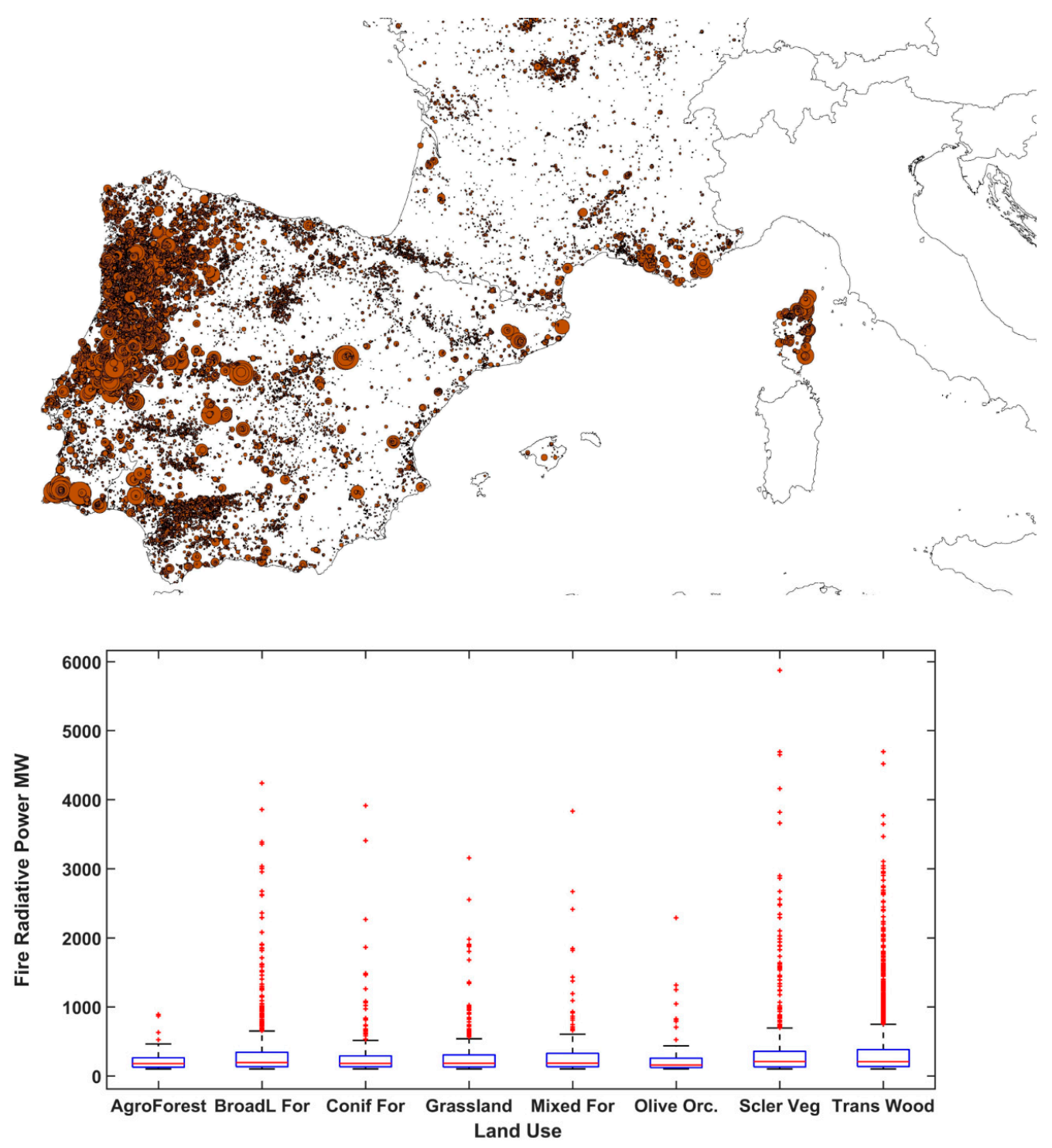

Figure 4. Distribution of fires in Portugal, Spain, and France for the period from 2000 to 2017 (upper panel). The center of the circle represents the location of the fire event and the diameter its relative intensity in megawatts. The lower panel depicts the boxplots of fire intensity with respect to land use, which were obtained by intersecting the fire data and CORINE 2012 land use database (see Materials and Methods for details). In each boxplot, the median value is indicated by the red horizontal line, the size of the box represents $50 \%$ of the observations, and the small black horizontal lines and red asterisks represent outlier values based on interquartile range estimates. Land use labels correspond to: 'AgroForest' for agroforestry areas; 'BroadL For' for forests dominated with broadleaves; 'Conif For' for forests dominated by conifers; 'Grasslands' for natural or managed herbaceous vegetation; 'Mixed For' for mixed forests of broadleaves and conifers; 'Olive Orc' for olive tree plantations; 'Scler Veg' for fire-prone sclerophylous vegetation; and 'Trans Wood' for transitional vegetation that may or may not regenerate into closed forests.

Indeed, extensification through agroforestry such as in montado and dehesa savanna-type areas in Portugal and Spain (Figures 2 and 5), integration of animal production, cork/firewood harvesting, and cereal cultivation are often presented as solutions to decreasing populations and managing fire risks in these regions $[11,13,23,24,27]$, a system type present in all Mediterranean countries. Maintaining open spaces in the landscape mosaic by keeping domestic herbivores, having low but sufficient tree density, 
and/or performing controlled burning allow agroforestry systems to contribute to the avoidance of massive fires that can accelerate rural abandonment. If land is abandoned, the probability of biomass accumulation increases, thus promoting new fires in a self-reinforcing process. In the next section, we analyze how the concomitant processes of species and emergent diseases on keystone tree species may hamper the use of agroforestry as an adaptation option.

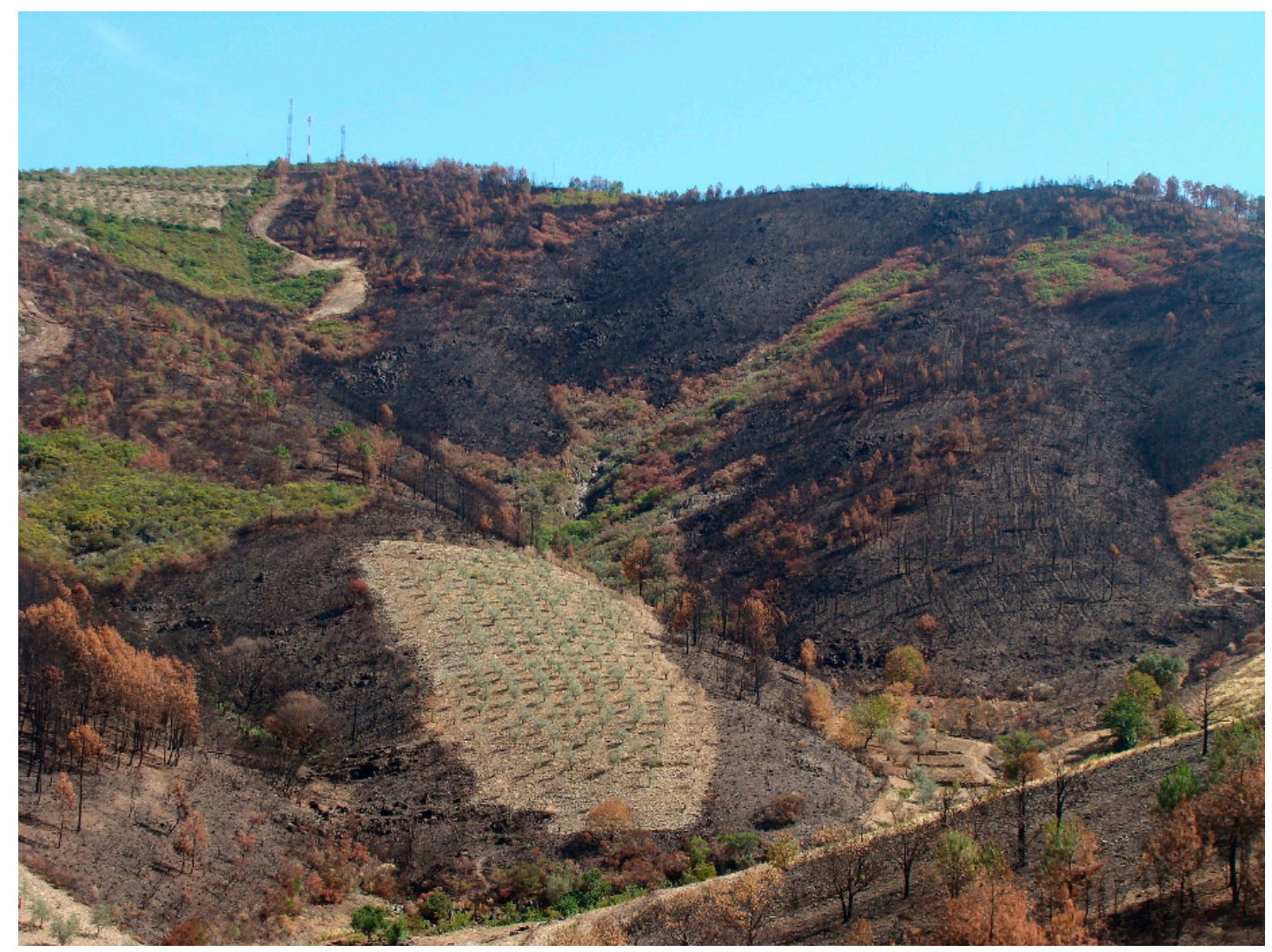

Figure 5. Landscape with a mosaic of olive, cherry, and chestnut groves after a 5000 ha burn in Las Hurdes (Extremadura region, Western Spain, August 2009). Note that the black areas coincide with pines and shrub lands, whereas unburnt areas are mostly cultivated with trees (photo by F. Pulido).

This first adaptation option, mainly hindered today by rural abandonment, requires people to continue to live in rural areas and manage their landscapes. However, this is highly limited by policies that do not encourage the use of mixed-vegetation systems. In this regard, agroforestry associations need to be actively engaged to receive any support from the Common Agricultural Policy [53] that is lagging in its implementation to promote alternate land uses. Subsidies targeting new ways of managing landscapes with traditional and innovative approaches would certainly play a role in stopping the rural exodus.

The second adaptation option would be less management intensive and more focused on natural areas where dry conditions would favor the establishment of stable evergreen populations. The overall strategy would consist of allowing and promoting the spread of evergreen species, as such forests are naturally adapted to the new conditions in which small-scale low- to medium-intensity fire regimes are part of the natural process. In fact, paleo-ecological data and vegetation models both suggest that forests based on different proportions of trees such as Quercus ilex, Q. pubescens, and Olea europea and shrubs such as Pistacia lentiscus and Phillyrea latifolia can produce stable vegetation types under the expected scenarios of climate change that include fire regimes [54]. In this context, land abandonment with the initial management of the abovementioned species could become an 
opportunity for rewilding many areas of Europe. Rewilding abandoned landscapes, compensated with fire prevention measures (e.g., grazing by megaherbivores), could become an alternative management system [55] and an opportunity for adaptation [56]. Rewilding could promote the development of "wild businesses" such as ecotourism and wildlife watching, which could in turn support local communities [45]. More data are required in this respect, and more field studies must be performed to improve our understanding of the impact of land abandonment and rewilding on biodiversity and ecosystem services [57], although recovering megafauna populations (either passively or with assistance) will probably contribute to the restoration of key ecosystem processes (e.g., energy and nutrient flows), while allowing human control of the landscape to decrease [58]. A second advantage of forest regrowth is that soil carbon content can increase in the soil after land abandonment [59], thus contributing to climate change mitigation as seen in certain plots in mainland Italy and Sicily along a climate gradient. This strategy will probably favor the cultivation of fast-growing tree species that require more water in specific areas where climate change effects are less pronounced. From a management perspective, the spread of evergreen species would be an active program or passive approach of natural regeneration, depending on the available resources and the decisions made by managers at the local level.

\subsection{Invasive Species and Diseases as Barriers to Implementing Agroforestry as an Adaptation Option}

Several barriers to climate change adaptation based on agroforestry exist along the selected area of study (Figure 1), mainly in terms of biological process like emerging pests and diseases and invasive species [60]. Keystone species in traditional agroforestry systems are subject to emergent diseases and pests. Holm and cork oaks are declining in the Iberian Peninsula due to a complex combination of biotic and abiotic factors [61]. Drought-stressed trees attacked by fungi in the genera Biscogniauxia and Diplodia, the Oomycete Phytophthora cinnamomi, and bark and wood borers such as Platypus cylindrus have been associated with the most serious cases [62]. In fact, P. cinnamomi is currently considered to play a major role in forest composition transitions in several parts of the world [63]. Likewise, the olive tree flower bacterium Xylella fastidiosa may expand its range as the climate changes, and along with the chestnut blight Cryphonectria parasitica [64], both make agroforestry based on these trees an inefficient alternative until resistant lines are identified.

Outside agroforestry areas, the pinewood nematode Bursaphelenchus xylophilus is an invasive species native to North America but found in the Iberian Peninsula since 1999 [65], which threatens the sustainability of conifer-based plantations or natural conifer forests. In Europe, the pinewood nematode is transmitted by the native long-horned beetle Monochamus galloprovincialis. The nematode induces pine wilt disease, which has become a major threat to European pine forests [65]. Up to $50 \%$ of infected trees can die within a few months of detecting the nematode, so preventive actions are very difficult. It is likely that climate change and globalization (timber exports) will cause B. xylophilus to extend its range to the large and very productive maritime pine plantations of the Landes Department in France. The Central Pyrenees have so far acted as a natural cold barrier that limits the movement of long-horned beetles, but climate change as well as the timber and plant trade are likely to decrease the effectiveness of this barrier, thus increasing the chance of the nematode becoming more dispersed [66].

Invasive species may change forests in ways that are difficult to predict, as they may or may not be useful in the context of new forms of agroforestry. Invasive or naturalized trees such as Ailanthus altissima, Robinia pseudoacacia, Quercus rubra, Prunus serotina, and Acer negundo are already spreading and colonizing abandoned fields and may become more common in the transitional zones between Mediterranean and temperate areas [67]. Nevertheless, these aggressive species are attractive for biomass production, as in the case of R. pseudoacacia [68], and they may thus be favored by the fuelwood sector (see below). Similarly, the false indigo bush Amorpha fruticosa is problematic in Western and Eastern Europe, because it is the main species that takes over abandoned grassland and agricultural areas, although many people accept its propagation because it attracts domestic bees and has phyto-pharmaceutical properties [69]. It can therefore be seen that current invasions along 
the gradient can offer clues as to how people are dealing with changes and how proactive long-term policies can be developed.

\subsection{Biomass Policies and Rapid Changes in Managed Forests}

Recent policies for producing fuel from forest biomass in Mediterranean areas may accelerate management schemes that change species composition at a very fast rate. Drought-resilient species like holm oak have been key local energy sources for centuries, as indicated by the widespread legacy of formerly coppiced woodland used by very small and sparse populations [70]. Today, the Mediterranean fuelwood sector is currently being developed to produce fuel on an industrial scale in various countries [71]. Mediterranean foresters regard fuelwood production to be an opportunity to use wood that would otherwise be unmarketable (because of slow growth, small quantities, or misshapen wood), but there is a clear mismatch between local productivity and biomass requirements. For example, two industrial-scale wood boilers were created in the French Mediterranean area in 2014, largely funded through national subsidies. These boilers will require more than $10^{6} \mathrm{~m}^{3}$ of wood per year to run, but only around $600,000 \mathrm{~m}^{3}$ of wood is produced in the area annually. Similar examples are beginning to emerge in several other Mediterranean areas, including Italy and Greece.

Foresters may tend to overexploit forests for the biomass industry, including the collection of wood residues that release nutrients for the next generation of trees. Soil impoverishment could soon mean that Eucalyptus, Populus, Salix, Paulownia, and monocultures of various species of Acacia could spread in countries like Spain, France, and Portugal, where mixed-species, long-rotation forests are currently found. These monocultures in turn risk being abandoned if timber policies are not implemented for the long term because of continued migration to urban areas, as has already occurred in Spain and Portugal. In addition, soils might become impoverished following intensive Eucalyptus plantations, which make it difficult for natural regeneration of native species to proceed. Mediterranean forests may become much less diverse with even-aged managed landscapes if biomass accumulation policies are generalized, thus complicating the implementation of a landscape management approach with open forest and agroforests in the future. Hence, managers need to be aware of ongoing trends at the ecological, social, and political levels in order to anticipate and manage drivers that may take their ecosystems toward undesirable adaptation paths, as explained in the next section.

\subsection{Early Warnings for Implementing Timely Policies}

We suggest that careful monitoring of forest health, fire regimes, and rural population are key factors to ensure that adaptation options can be implemented for the forest sector, whether in terms of agroforestry or any other management option that can deal with fire and drought risks. Hence, it would be desirable if monitoring were implemented to avoid making poor decisions when it is already too late, given that forest cycles are longer than those of human generations.

Regarding tree mortality prevention, tools are required to forecast the tree species (or populations) that are more likely to die or undergo dieback in response to water deficiency, including defoliation [72] and tree-ring information. Tree rings contain some of this information, which can be reconstructed in dendrochronological studies by linking tree growth to climate data and drought stress. Dendrochronology can also be used to assess the vulnerability of forests to drought and give early warnings about tree death and dieback, but the specific responses of different species to local climate changes must also be considered [38,39].

From a social and economic perspective, several early warnings of the breakdown of Mediterranean and temperate forest SESs can be identified from data on temporal changes in human demography, land use, tree coverage, local climates, and other factors. Using time series, it is theoretically possible to model SESs that encompass urban migration, rural abandonment, and forest regrowth dynamics, and then use such models to provide indices of thresholds that should be avoided. For instance, in a model presented by Figueiredo and Pereira [73], SESs exhibited regime shifts that could be triggered either by a tipping point being crossed in terms of migration 
(i.e., most inhabitants likely to leave a rural area once a given percentage of the population has left) or in terms of the balance between forest and agriculture (i.e., it becomes too costly to deforest and cultivate land once too much forest growth has occurred). Without systematically acquiring temporal series data, it seems difficult for the reality of models applied at the local scale to be improved and for managers to make educated decisions of adaptation. We summarized the variables that could be monitored in Table 1.

Table 1. List of variables, methods, and policy recommendations related to early warnings in the studied social-ecological gradient. Threshold values for each listed variable that can provoke a profound change in the system are unknown.

\begin{tabular}{|c|c|c|c|}
\hline Process & Variables & Methods & Policy Recommendation \\
\hline \multicolumn{4}{|l|}{ Ecological Processes } \\
\hline $\begin{array}{l}\text { Decrease in productivity and } \\
\text { increased mortality because of } \\
\text { drought stress }\end{array}$ & $\begin{array}{l}\text { Leaf drop, defoliation, stem } \\
\text { dieback, temporal variation in } \\
\text { tree rings with respect to } \\
\text { climate }\end{array}$ & $\begin{array}{l}\text { Dendrochronology, remote } \\
\text { sensing, field monitoring } \\
\text { programs, drought monitors }\end{array}$ & $\begin{array}{l}\text { Support forest monitoring } \\
\text { programs, promote alternative } \\
\text { management to reduce competition } \\
\text { between trees to cope with water } \\
\text { stress }\end{array}$ \\
\hline $\begin{array}{l}\text { Functional and compositional } \\
\text { forest changes }\end{array}$ & $\begin{array}{l}\text { Proportion of evergreen } \\
\text { species }\end{array}$ & $\begin{array}{l}\text { Field inventories, remote } \\
\text { sensing }\end{array}$ & Support forest monitoring programs \\
\hline $\begin{array}{l}\text { Species invasions including } \\
\text { pathogens and pests }\end{array}$ & $\begin{array}{l}\text { Levels of infection in keystone } \\
\text { species }\end{array}$ & $\begin{array}{l}\text { Mapping of disease spread, } \\
\text { climate/landscape models of } \\
\text { disease spread }\end{array}$ & $\begin{array}{l}\text { Promote and maintain cultivar } \\
\text { diversity, promote mixed cultures, } \\
\text { support research for resistant } \\
\text { cultivars }\end{array}$ \\
\hline Spontaneous forest regrowth & $\begin{array}{l}\text { Tree density, biomass, shrub } \\
\text { density }\end{array}$ & $\begin{array}{l}\text { Field inventories, remote } \\
\text { sensing }\end{array}$ & $\begin{array}{l}\text { Study forest management practices } \\
\text { and fire control }\end{array}$ \\
\hline $\begin{array}{l}\text { Change in local climatic } \\
\text { conditions }\end{array}$ & $\begin{array}{l}\text { Mean, annual, and variability } \\
\text { of temperature and } \\
\text { precipitation }\end{array}$ & Weather stations & $\begin{array}{l}\text { Promote, maintain, and share } \\
\text { regional high-resolution climate } \\
\text { data }\end{array}$ \\
\hline \multicolumn{4}{|l|}{ Social and Economic Processes } \\
\hline Land abandonment & $\begin{array}{l}\text { Diversity of agricultural } \\
\text { activities, rural/urban } \\
\text { demographic trends, } \\
\text { proportion of barren land }\end{array}$ & $\begin{array}{l}\text { Census of human populations, } \\
\text { remote sensing }\end{array}$ & $\begin{array}{l}\text { Promote the economic activity of } \\
\text { remote areas through labeling and } \\
\text { certification, include agroforesters } \\
\text { in fire prevention programs }\end{array}$ \\
\hline Husbandry decline & $\begin{array}{l}\text { Numbers and density of } \\
\text { different types of husbandry } \\
\text { (intensive or open), type of } \\
\text { species, price of } \\
\text { animal-derived products }\end{array}$ & $\begin{array}{l}\text { Husbandry census, market } \\
\text { analysis }\end{array}$ & $\begin{array}{l}\text { Promote local products with labels } \\
\text { and open husbandry to complement } \\
\text { agroforestry areas and fire control }\end{array}$ \\
\hline $\begin{array}{l}\text { Mismatches between local } \\
\text { practices and market demands }\end{array}$ & $\begin{array}{l}\text { Statistics on timber use, prices } \\
\text { of wood biomass versus } \\
\text { finished wood }\end{array}$ & $\begin{array}{l}\text { Market statistics analysis, } \\
\text { biomass quotas per region, } \\
\text { electricity demands }\end{array}$ & $\begin{array}{l}\text { Balance biomass extraction with } \\
\text { alternative energy sources like solar } \\
\text { energy }\end{array}$ \\
\hline Disruption of water cycles & $\begin{array}{l}\text { Agricultural and urban levels } \\
\text { of water use, levels of water } \\
\text { availability }\end{array}$ & $\begin{array}{l}\text { Water availability assessment } \\
\text { in tree-based agriculture }\end{array}$ & $\begin{array}{l}\text { Promote the use and } \\
\text { commercialization of alternative } \\
\text { non-water-thirsty crops } \\
\text { (non-irrigated agroforestry), } \\
\text { monitor deep water sources }\end{array}$ \\
\hline
\end{tabular}

\section{Discussion and Conclusions}

The worst-case scenario, at least from a fire management perspective, would be a very rapid spreading of non-productive scrubs, concomitant with an uncontrolled increase in fire frequency and magnitude along the studied ecotone, which would irreversibly transform the current vegetation. Such rapid change, reinforced by increased land abandonment and rural unemployment, would further affect the loss of local knowledge, and as a result, opportunities for landscape management would be missed. A rapid expansion of these ecological and social conditions would further affect the newly created biomass value chains that target remnant forests and promote the use of fast-growing exotic species. The biomass industry would probably continue for a number of years with a very fragile equilibrium until all available biomass had been extracted, with the spread of fires into newly created plantations being uncontrollable because of unmanaged landscapes. 
The best-case scenario would be the continuity of land use based on agroforestry and open husbandry in the Mediterranean area and the emergence of land use that reinterprets these approaches in temperate areas. The "mosaic approach" presented here would promote a diversified low-impact land use of landscapes where areas with micro-climates can be used as refugia for local biodiversity [74]. This continuity requires political commitment to allow for a transition to be gradually implemented for different kinds of land use in a preventive way. Acting after the combined effects of land abandonment, fire, and rural exodus have already turned these areas into poorly managed regimes would probably be more expensive and have fewer chances of success. The use of biomass for producing heat and electricity would be tailored to these new conditions, designed especially to operate at very local scales and as a complement to other renewable energy resources. In summary, the worst-case scenario would promote a fire-prone situation, while the best-case scenario would promote the co-existence of human activities, forest management, and small-scale fires as part of a natural process that maintains high biodiversity levels. Regardless, the adaptation to the new conditions along this ecotonal area requires increased landscape management compared to the current levels, as a passive transformation of vegetation can have unpredictable results because of invasive species.

The type of analysis performed here is generally termed a "space-for-time substitution" method, because spatial patterns, like vegetation gradients, are taken as examples of change over time. Space-for-time approaches are not new in ecology, and their strengths and weaknesses are well documented. This reasoning can be seen as complementary to the acquisition of experimental data [75], not as a substitute for understanding the underlying mechanisms, but as an option if no long-term data exist. Space-for-time substitution has recently been used, for instance, to: (a) characterize past effects on biodiversity at large geological scales [76]; (b) improve our understanding of species responses to land-use changes and build future response scenarios [77]; and (c) predict climate change effects on plant communities in continuous altitudinal ecotones [11]. However, the approach has not yet been used comprehensively in social-ecological studies to improve our understanding of alternative scenarios of adaptation along climatic gradients. We therefore hope that our analysis with forests can contribute to a wider use of space-for-time substitutions for other sectors such as water use in agriculture, urban planning for warmer climates, and so forth.

Our general conclusions can be summarized as follows: (a) preventing rural abandonment unless land abandonment is considered to be a rewilding opportunity; (b) implementing management options for more open vegetation if fire and drought hazards are the main drivers; and (c) articulating long-term monitoring programs to identify the spread of pests, pathogens, or invasive species as well as early warning signals to climate change. Systems such as the dehesa or montado, which exist in all countries in the Mediterranean basin in one form or another, can prevent rural exodus by creating specialized jobs in rural zones for their management and preservation while creating fire barriers within woodland areas. If agroforestry is applied outside of the Mediterranean basin as a viable adaptation option, it will need to be modified to suit ecological and social conditions beyond their current distributions in order to be successful.

Supplementary Materials: The following are available online at http:/ /www.mdpi.com/2071-1050/10/9/3065/s1. Figure S1: Temperature and precipitation patterns of the study zones and major forest types. Table S1: Summary table of forest transitions currently reported by the literature used for Figure 2 in the main text.

Author Contributions: J.F.-M., M.A.Z., P.R.-B., and J.J.C. conceived the paper; L.N., R.S., C.B., P.D., S.R., F.P., and M.B.-G. contributed with specific sections of the manuscript; E.G., P.R.-B., L.M., and M.T. constructed the forest transition table; F.P. contributed the study case; J.F.-M. lead the writing of the article and conducted the land use and fire analysis, and all authors contributed with concepts, figures, references, and text editing.

Funding: This research was funded by a small network grant provided by the LabEx-BASC French research consortium granted to J.F.-M., S.D., and H.L. M.A.Z. and P.R.-B. were supported by the grant FUNDIVER (MINECO, CGL2015-69186-C2-2-R). P.R.-B. was funded by the Talent Attraction Grant of the Madrid Community grant number 2016-T2/AMB-1665. V.P. was funded by FCT-The Foundation for Science and Technology grant number SFRH/BPD/80726/2011. 
Acknowledgments: This opinion paper is the result of two workshops held in Paris in 2015 and in Madrid in 2016 hosted at the Universidad de Alcalá, as well as subsequent exchanges. We also wish to thank two anonymous reviewers that greatly improved the quality of the manuscript.

Conflicts of Interest: The authors declare no conflict of interest. The founding sponsors had no role in the study design, the collection, analyses, or interpretation of data, the writing of the manuscript, or the decision to publish the results.

\section{References}

1. Bellassen, V.; Luyssaert, S. Carbon sequestration: Managing forests in uncertain times. Nature 2014, 506, 153-155. [CrossRef] [PubMed]

2. Miettinen, J.; Ollikainen, M.; Nieminen, T.M.; Ukonmaanaho, L.; Lauren, A.; Hynynen, J.; Lehtonen, M.; Valsta, L. Whole-tree harvesting with stump removal versus stem-only harvesting in peatlands when water quality, biodiversity conservation and climate change mitigation matter. For. Policy Econ. 2014, 47, 25-35. [CrossRef]

3. Greenwood, S.; Ruiz-Benito, P.; Martínez-Vilalta, J.; Lloret, F.; Kitzberger, T.; Allen, C.D.; Fensham, R.; Laughlin, D.C.; Kattge, J.; Bönisch, G.; et al. Tree mortality across biomes is promoted by drought intensity, lower wood density and higher specific leaf area. Ecol. Lett. 2017, 20, 539-553. [CrossRef] [PubMed]

4. Pausas, J.G.; Fernández-Muñoz, S. Fire regime changes in the Western Mediterranean Basin: From fuel-limited to drought-driven fire regime. Clim. Chang. 2012, 110, 215-226. [CrossRef]

5. Schelhaas, M.J.; Hengeveld, G.; Moriondo, M.; Reinds, G.J.; Kundzewicz, Z.W.; Ter Maat, H.; Bindi, M. Assessing risk and adaptation options to fires and windstorms in European forestry. Mitig. Adapt. Strateg. Glob. Chang. 2010, 15, 681-701. [CrossRef]

6. Janse, J.D. Bacterial diseases that may or do emerge, with (possible) economic damage for Europe and the Mediterranean basin: Notes on epidemiology, risks, prevention and management on first occurrence. J. Plant Pathol. 2012, 94, S5-S29.

7. Allen, C.D.; Breshears, D.D. Drought-induced shift of a forest-woodland ecotone: Rapid landscape response to climate variation. Proc. Natl. Acad. Sci. USA 1998, 95, 14839-14842. [CrossRef] [PubMed]

8. Cudlin, P.; Klopcic, M.; Tognetti, R.; Malis, F.; Alados, C.L.; Bebi, P.; Grunewald, K.; Zhiyanski, M.; Andonowski, V.; La Porta, N.; et al. Drivers of treeline shift in different European mountains. Clim. Res. 2017, 73, 135-150. [CrossRef]

9. Evans, P.; Brown, C.D. The boreal-temperate forest ecotone response to climate change. Environ. Rev. 2017, 25, 423-431. [CrossRef]

10. King, D.A.; Bachelet, D.M.; Symstad, A.J. Climate change and fire effects on a prairie-woodland ecotone: Projecting species range shifts with a dynamic global vegetation model. Ecol. Evol. 2013, 3, 5076-5097. [CrossRef] [PubMed]

11. Sundqvist, M.K.; Sanders, N.J.; Wardle, D.A. Community and Ecosystem Responses to Elevational Gradients: Processes, Mechanisms, and Insights for Global Change. Annu. Rev. Ecol. Evol. Syst. 2013, 44, 261-280. [CrossRef]

12. Buntgen, U.; Tegel, W.; Nicolussi, K.; McCormick, M.; Frank, D.; Trouet, V.; Kaplan, J.O.; Herzig, F.; Heussner, K.U.; Wanner, H.; et al. 2500 Years of European Climate Variability and Human Susceptibility. Science 2011, 331, 578-582. [CrossRef] [PubMed]

13. Camarero, J.J.; Gazol, A.; Sancho-Benages, S.; Sanguesa-Barreda, G. Know your limits? Climate extremes impact the range of Scots pine in unexpected places. Ann. Bot. 2015, 116, 917-927. [CrossRef] [PubMed]

14. Sanchez-Salguero, R.; Navarro-Cerrillo, R.M.; Swetnam, T.W.; Zavala, M.A. Is drought the main decline factor at the rear edge of Europe? The case of southern Iberian pine plantations. For. Ecol. Manag. 2012, 271, 158-169. [CrossRef]

15. Pautasso, M. Ten Simple Rules for Writing a Literature Review. PLoS Comput. Biol. 2013, 9, e1003149. [CrossRef] [PubMed]

16. IPCC. Climate Change 2013: The Physical Science Basis. Contribution of Working Group I to the Fifth Assessment Report of the Intergovernmental Panel on Climate Change; Cambridge University Press: Cambridge, UK; New York, NY, USA, 2013; 1535p. 
17. Ruti, P.M.; Somot, S.; Giorgi, F.; Dubois, C.; Flaounas, E.; Obermann, A.; Dell'Aquila, A.; Pisacane, G.; Harzallah, A.; Lombardi, E.; et al. MED-CORDEX initiative for Mediterranean climate studies. Bull. Am. Meteorol. Soc. 2016, 97, 1187-1208. [CrossRef]

18. Stefanon, M.; Martin-StPaul, N.K.; Leadley, P.; Bastin, S.; Dell'Aquila, A.; Drobinski, P.; Gallardo, C. Testing climate models using an impact model: What are the advantages? Clim. Chang. 2015, 131, 649-661. [CrossRef]

19. Jacob, D.; Petersen, J.; Eggert, B.; Alias, A.; Christensen, O.B.; Bouwer, L.M.; Braun, A.; Colette, A.; Déqué, M.; Georgievski, G.; et al. EURO-CORDEX: New high-resolution climate change projections for European impact research. Reg. Environ. Chang. 2014, 14, 563-578. [CrossRef]

20. Drobinski, P.; Alonzo, B.; Bastin, S.; Da Silva, N.; Muller, C. Scaling of precipitation extremes with temperature in the French Mediterranean region: What explains the hook shape? J. Geophys. Res. Atmos. 2016, 121, 3100-3119. [CrossRef]

21. Benito-Garzón, M.; Leadley, P.W.; Fernández-Manjarrés, J.F. Assessing global biome exposure to climate change through the Holocene-Anthropocene transition. Glob. Ecol. Biogeogr. 2014, 23, 235-244. [CrossRef]

22. Bernués, A.; Ruiz, R.; Olaizola, A.; Villalba, D.; Casasús, I. Sustainability of pasture-based livestock farming systems in the European Mediterranean context: Synergies and trade-offs. Livest. Sci. 2011, 139, 44-57. [CrossRef]

23. Bugalho, M.N.; Caldeira, M.C.; Pereira, J.S.; Aronson, J.; Pausas, J.G. Mediterranean cork oak savannas require human use to sustain biodiversity and ecosystem services. Front. Ecol. Environ. 2011, 9, 278-286. [CrossRef]

24. Blondel, J. The 'Design' of Mediterranean Landscapes: A Millennial Story of Humans and Ecological Systems during the Historic Period. Hum. Ecol. 2006, 34, 713-729. [CrossRef]

25. den Herder, M.; Moreno, G.; Mosquera-Losada, R.M.; Palma, J.H.N.; Sidiropoulou, A.; Santiago Freijanes, J.J.; Crous-Duran, J.; Paulo, J.A.; Tomé, M.; Pantera, A.; et al. Current extent and stratification of agroforestry in the European Union. Agric. Ecosyst. Environ. 2017, 241, 121-132. [CrossRef]

26. Olson, D.M.; Dinerstein, E.; Wikramanayake, E.D.; Burgess, N.D.; Powell, G.V.N.; Underwood, E.C.; D'Amico, J.A.; Itoua, I.; Strand, H.E.; Morrison, J.C.; et al. Terrestrial Ecoregions of the World: A New Map of Life on Earth. BioScience 2001, 51, 933-938. [CrossRef]

27. Gauquelin, T.; Michon, G.; Joffre, R.; Duponnois, R.; Génin, D.; Fady, B.; Bou Dagher-Kharrat, M.; Derridj, A.; Slimani, S.; Badri, W.; et al. Mediterranean forests, land use and climate change: A social-ecological perspective. Reg. Environ. Chang. 2018, 18, 623-636. [CrossRef]

28. Moreno, M.V.; Conedera, M.; Chuvieco, E.; Pezzatti, G.B. Fire regime changes and major driving forces in Spain from 1968 to 2010. Environ. Sci. Policy 2014, 37, 11-22. [CrossRef]

29. Silva, J.S.; Vaz, P.; Moreira, F.; Catry, F.; Rego, F.C. Wildfires as a major driver of landscape dynamics in three fire-prone areas of Portugal. Landsc. Urban Plan. 2011, 101, 349-358. [CrossRef]

30. Ruiz-Benito, P.; Gómez-Aparicio, L.; Zavala, M.A. Large-scale assessment of regeneration and diversity in Mediterranean planted pine forests along ecological gradients. Divers. Distrib. 2012, 18, 1092-1106. [CrossRef]

31. Naudts, K.; Chen, Y.; McGrath, M.J.; Ryder, J.; Valade, A.; Otto, J. Europe's forest management did not mitigate climate warming. Science 2016, 351, 597-600. [CrossRef] [PubMed]

32. Galiano, L.; Martinez-Vilalta, J.; Lloret, F. Drought-induced multifactor decline of scots pine in the Pyrenees and potential vegetation change by the expansion of co-occurring oak species. Ecosystems 2010, 13, 978-991. [CrossRef]

33. Galiano, L.; Martínez-Vilalta, J.; Sabaté, S.; Lloret, F. Determinants of drought effects on crown condition and their relationship with depletion of carbon reserves in a Mediterranean holm oak forest. Tree Physiol. 2012, 32, 478-489. [CrossRef] [PubMed]

34. Peñuelas, J.; Boada, M. A global change-induced biome shift in the Montseny mountains (NE Spain). Glob. Chang. Biol. 2003, 9, 131-140. [CrossRef]

35. Urbieta, I.R.; García, L.V.; Zavala, M.A.; Marañón, T. Mediterranean pine and oak distribution in southern Spain: Is there a mismatch between regeneration and adult distribution? J. Veg. Sci. 2011, 22, 18-31. [CrossRef]

36. Delzon, S.; Urli, M.; Samalens, J.C.; Lamy, J.B.; Lischke, H.; Sin, F.; Zimmermann, N.E.; Porte, A.J. Field evidence of colonisation by Holm oak, at the Northern margin of its distribution Range, during the Anthropocene period. PLoS ONE 2013, 8, e80443. [CrossRef] [PubMed] 
37. Ruiz-Benito, P.; Ratcliffe, S.; Zavala, M.A.; Martínez-Vilalta, J.; Vilà-Cabrera, A.; Lloret, F.; Madrigal-González, J.; Wirth, C.; Greenwood, S.; Kändler, G.; et al. Climate- and successional-related changes in functional composition of European forests are strongly driven by tree mortality. Glob. Chang. Biol. 2017, 23, 4162-4176. [CrossRef] [PubMed]

38. Huang, J.; Yu, H.; Guan, X.; Wang, G.; Guo, R. Accelerated dryland expansion under climate change. Nat. Clim. Chang. 2016, 6, 166-171. [CrossRef]

39. Prudhomme, C.; Giuntoli, I.; Robinson, E.L.; Clark, D.B.; Arnell, N.W.; Dankers, R.; Fekete, B.M.; Franssen, W.; Gerten, D.; Gosling, S.N.; et al. Hydrological droughts in the 21st century, hotspots and uncertainties from a global multimodel ensemble experiment. Proc. Natl. Acad. Sci. USA 2014, 111, 3262-3267. [CrossRef] [PubMed]

40. Yu, M.; Wang, G.; Parr, D.; Ahmed, K.F. Future changes of the terrestrial ecosystem based on a dynamic vegetation model driven with RCP8.5 climate projections from 19 GCMs. Clim. Chang. 2014, 127, 257-271. [CrossRef]

41. Levers, C.; Müller, D.; Erb, K.; Haberl, H.; Jepsen, M.R.; Metzger, M.J.; Meyfroidt, P.; Plieninger, T.; Plutzar, C.; Stürck, J.; et al. Archetypical patterns and trajectories of land systems in Europe. Reg. Environ. Chang. 2018, 18, 715-732. [CrossRef]

42. Beilin, R.; Lindborg, R.; Stenseke, M.; Pereira, H.M.; Llausàs, A.; Slätmo, E.; Cerqueira, Y.; Navarro, L.; Rodrigues, P.; Reichelt, N.; et al. Analysing how drivers of agricultural land abandonment affect biodiversity and cultural landscapes using case studies from Scandinavia, Iberia and Oceania. Land Use Policy 2014, 36, 60-72. [CrossRef]

43. Estel, S.; Kuemmerle, T.; Alcántara, C.; Levers, C.; Prishchepov, A.; Hostert, P. Mapping farmland abandonment and recultivation across Europe using MODIS NDVI time series. Remote Sens. Environ. 2015, 163, 312-325. [CrossRef]

44. Lasanta, T.; Nadal-Romero, E.; Arnáez, J. Managing abandoned farmland to control the impact of re-vegetation on the environment. The state of the art in Europe. Environ. Sci. Policy 2015, 52, 99-109. [CrossRef]

45. Stürck, J.; Levers, C.; Zanden, E.H. v. d.; Schulp, C.J.E.; Verkerk, P.J.; Kuemmerle, T.; Helming, J.; Lotze-Campen, H.; Tabeau, A.; Popp, A.; et al. Simulating and delineating future land change trajectories across Europe. Reg. Environ. Chang. 2015, 3, 1-17. [CrossRef]

46. San-Miguel-Ayanz, J.; Moreno, J.M.; Camia, A. Analysis of large fires in European Mediterranean landscapes: Lessons learned and perspectives. For. Ecol. Manag. 2013, 294, 11-22. [CrossRef]

47. Cocca, G.; Sturaro, E.; Gallo, L.; Ramanzin, M. Is the abandonment of traditional livestock farming systems the main driver of mountain landscape change in Alpine areas? Land Use Policy 2012, 29, 878-886. [CrossRef]

48. Queiroz, C.; Beilin, R.; Folke, C.; Lindborg, R. Farmland abandonment: Threat or opportunity for biodiversity conservation? A global review. Front. Ecol. Environ. 2014, 12, 288-296. [CrossRef]

49. Plieninger, T.; Hui, C.; Gaertner, M.; Huntsinger, L. The Impact of Land Abandonment on Species Richness and Abundance in the Mediterranean Basin: A Meta-Analysis. PLoS ONE 2014, 9, e98355. [CrossRef] [PubMed]

50. Lenda, M.; Skórka, P.; Knops, J.M.H.; Moroń, D.; Tworek, S.; Woyciechowski, M. Plant establishment and invasions: An increase in a seed disperser combined with land abandonment causes an invasion of the non-native walnut in Europe. Proc. R. Soc. Lond. B Biol. Sci. 2012, 279, 1491-1497. [CrossRef] [PubMed]

51. Modugno, S.; Balzter, H.; Cole, B.; Borrelli, P. Mapping regional patterns of large forest fires in Wildland-Urban Interface areas in Europe. J. Environ. Manag. 2016, 172, 112-126. [CrossRef] [PubMed]

52. Amatulli, G.; Camia, A.; San-Miguel-Ayanz, J. Estimating future burned areas under changing climate in the EU-Mediterranean countries. Sci. Total Environ. 2013, 450-451, 209-222. [CrossRef] [PubMed]

53. Mosquera-Losada, M.R.; Santiago-Freijanes, J.J.; Pisanelli, A.; Rois-Díaz, M.; Smith, J.; den Herder, M.; Moreno, G.; Ferreiro-Domínguez, N.; Malignier, N.; Lamersdorf, N.; et al. Agroforestry in the European common agricultural policy. Agrofor. Syst. 2018, 92, 1117-1127. [CrossRef]

54. Henne, P.D.; Ché, E.; Jörg, F.; Daniele, C.; Camilla, C.; Tommaso, L.M.; Salvatore, P.; Marco, C.; Orla, D.; Willy, T. Reviving extinct Mediterranean forest communities may improve ecosystem potential in a warmer future. Front. Ecol. Environ. 2015, 13, 356-362. [CrossRef]

55. Navarro, L.M.; Pereira, H.M. Rewilding Abandoned Landscapes in Europe. Ecosystems 2012, 15, 900-912. [CrossRef] 
56. Root-Bernstein, M.; Guerrero-Gatica, M.; Piña, L.; Bonacic, C.; Svenning, J.-C.; Jaksic, F.M. Rewilding-inspired transhumance for the restoration of semiarid silvopastoral systems in Chile. Reg. Environ. Chang. 2016, 5, 1381-1396. [CrossRef]

57. Svenning, J.-C.; Pedersen, P.B.M.; Donlan, C.J.; Ejrnæs, R.; Faurby, S.; Galetti, M.; Hansen, D.M.; Sandel, B.; Sandom, C.J.; Terborgh, J.W.; et al. Science for a wilder Anthropocene: Synthesis and future directions for trophic rewilding research. Proc. Natl. Acad. Sci. USA 2016, 113, 898-906. [CrossRef] [PubMed]

58. Fernández, N.; Navarro, L.M.; Pereira, H.M. Rewilding: A Call for Boosting Ecological Complexity in Conservation. Conserv. Lett. 2017, 10, 276-278. [CrossRef]

59. Alberti, G.; Leronni, V.; Piazzi, M.; Petrella, F.; Mairota, P.; Peressotti, A.; Piussi, P.; Valentini, R.; Gristina, L.; La Mantia, T.; et al. Impact of woody encroachment on soil organic carbon and nitrogen in abandoned agricultural lands along a rainfall gradient in Italy. Reg. Environ. Chang. 2011, 11, 917-924. [CrossRef]

60. Gómez-Aparicio, L.; Ibáñez, B.; Serrano, M.S.; De Vita, P.; Ávila, J.M.; Pérez-Ramos, I.M.; García, L.V.; Esperanza, S.M.; Marañón, T. Spatial patterns of soil pathogens in declining Mediterranean forests: Implications for tree species regeneration. New Phytol. 2012, 194, 1014-1024. [CrossRef] [PubMed]

61. Ibáñez, B.; Ibáñez, I.; Gómez-Aparicio, L.; Ruiz-Benito, P.; García, L.V.; Marañón, T. Contrasting effects of climate change along life stages of a dominant tree species: The importance of soil-climate interactions. Divers. Distrib. 2014, 20, 872-883. [CrossRef]

62. Branco, M.; Bragança, H.; Sousa, E.; Phillips, A.J. Pests and Diseases in Portuguese Forestry: Current and New Threats. In Forest Context and Policies in Portugal: Present and Future Challenges; Reboredo, F., Ed.; Springer International Publishing: Cham, Switzerland, 2014; pp. 117-154.

63. Sena, K.; Crocker, E.; Vincelli, P.; Barton, C. Phytophthora cinnamomi as a driver of forest change: Implications for conservation and management. For. Ecol. Manag. 2018, 409, 799-807. [CrossRef]

64. Santini, A.; Ghelardini, L.; De Pace, C.; Desprez-Loustau, M.L.; Capretti, P.; Chandelier, A.; Cech, T.; Chira, D.; Diamandis, S.; Gaitniekis, T.; et al. Biogeographical patterns and determinants of invasion by forest pathogens in Europe. New Phytol. 2013, 197, 238-250. [CrossRef] [PubMed]

65. Nunes da Silva, M.; Solla, A.; Sampedro, L.; Zas, R.; Vasconcelos, M.W. Susceptibility to the pinewood nematode (PWN) of four pine species involved in potential range expansion across Europe. Tree Physiol. 2015, 35, 987-999. [CrossRef] [PubMed]

66. Robinet, C.; Roques, A.; Pan, H.; Fang, G.; Ye, J.; Zhang, Y.; Sun, J. Applying a spread model to identify the entry points from which the pine wood nematode, the vector of pine wilt disease, would spread most rapidly across Europe. Biol. Invasions 2011, 13, 2981-2995. [CrossRef]

67. Camenen, E.; Porté, A.J.; Benito Garzón, M. American trees shift their niches when invading Western Europe: Evaluating invasion risks in a changing climate. Ecol. Evol. 2016, 6, 7263-7275. [CrossRef] [PubMed]

68. Sitzia, T.; Campagnaro, T.; Dainese, M.; Cierjacks, A. Plant species diversity in alien black locust stands: A paired comparison with native stands across a north-Mediterranean range expansion. For. Ecol. Manag. 2012, 285, 85-91. [CrossRef]

69. Kozuharova, E.; Matkowski, A.; Woźniak, D.; Simeonova, R.; Naychov, Z.; Malainer, C.; Mocan, A.; Nabavi, S.M.; Atanasov, A.G. Amorpha fruticosa-A Noxious Invasive Alien Plant in Europe or a Medicinal Plant against Metabolic Disease? Front. Pharmacol. 2017, 8, 333. [CrossRef] [PubMed]

70. Cotillas, M.; Espelta, J.M.; Sánchez-Costa, E.; Sabaté, S. Aboveground and belowground biomass allocation patterns in two Mediterranean oaks with contrasting leaf habit: An insight into carbon stock in young oak coppices. Eur. J. For. Res. 2016, 135, 243-252. [CrossRef]

71. González, A.; Riba, J.-R.; Puig, R.; Navarro, P. Review of micro- and small-scale technologies to produce electricity and heat from Mediterranean forests' wood chips. Renew. Sustain. Energy Rev. 2015, 43, 143-155. [CrossRef]

72. Poyatos, R.; Aguadé, D.; Galiano, L.; Mencuccini, M.; Martínez-Vilalta, J. Drought-induced defoliation and long periods of near-zero gas exchange play a key role in accentuating metabolic decline of Scots pine. New Phytol. 2013, 200, 388-401. [CrossRef] [PubMed]

73. Figueiredo, J.; Pereira, H.M. Regime shifts in a socio-ecological model of farmland abandonment. Landsc. Ecol. 2011, 26, 737-749. [CrossRef]

74. Keppel, G.; Van Niel, K.P.; Wardell-Johnson, G.W.; Yates, C.J.; Byrne, M.; Mucina, L.; Schut, A.G.T.; Hopper, S.D.; Franklin, S.E. Refugia: Identifying and understanding safe havens for biodiversity under climate change. Glob. Ecol. Biogeogr. 2012, 21, 393-404. [CrossRef] 
75. Fukami, T.; Wardle, D.A. Long-term ecological dynamics: Reciprocal insights from natural and anthropogenic gradients. Proc. R. Soc. Lond. B Biol. Sci. 2005, 272, 2105-2115. [CrossRef] [PubMed]

76. Blois, J.L.; Williams, J.W.; Fitzpatrick, M.C.; Jackson, S.T.; Ferrier, S. Space can substitute for time in predicting climate-change effects on biodiversity. Proc. Natl. Acad. Sci. USA 2013, 110, 9374-9379. [CrossRef] [PubMed]

77. Proença, V.; Pereira, H.M. Species-area models to assess biodiversity change in multi-habitat landscapes: The importance of species habitat affinity. Basic Appl. Ecol. 2013, 14, 102-114. [CrossRef]

(C) 2018 by the authors. Licensee MDPI, Basel, Switzerland. This article is an open access article distributed under the terms and conditions of the Creative Commons Attribution (CC BY) license (http:/ / creativecommons.org/licenses/by/4.0/). 